\title{
Effects of clay mineral and physico-chemical variables on sandstone rock permeability
}

\author{
Khabat MAhmad,' Ferenc Kristály, ${ }^{2}$ Zoltan Turzo,' Roland Dócs ${ }^{3}$ \\ 'Institute of Petroleum and Natural Gas, University of Miskolc, Hungary \\ ${ }^{2}$ Institute of Mineralogy and Geology, University of Miskolc, Hungary \\ ${ }^{3}$ Research Institute of Applied Earth Sciences, University of Miskolc, Hungary
}

Correspondence: Amir Jahanbakhsh, Research Centre for Carbon Solutions, Heriot-Watt University, Edinburgh, United Kingdom, Email A.Jahanbakhsh@hw.ac.uk

Received: January 05, 20I8 | Published: February I5, 2018

Copyright@ 2018 Ahmad et al. This is an open access article distributed under the terms of the Creative Commons Attribution License, which permits unrestricted use, distribution, and reproduction in any medium, provided the original author and source are credited.

\begin{abstract}
In this paper we highlighted the effect of clay mineralogy and the influence of physico-chemical factors on coagulation- dispersion processes and the rate of pore throat bridging by clays. In particular, we describe the effect of different $\mathrm{pH}$ (acidic 2.5 and alkaline 9.5 ) and the effect of salinity (NaCl) on the stability of clay particles in siliciclastic rocks and their influence on the rock permeability which are often ignored in reservoir engineering literature. We conducted the first experiments on powder (0.05-0.1 mm grain size) samples for tracking mineral reactions and core plugs for permeability. X-ray diffraction (XRD) was run for whole-rock and clay fraction by diagnostic treatments to specify types of clay minerals and to calculate the percentage of each type.

The composition of starting material is quartz dominant, with carbonates (dolomite, calcite), feldspars (albite, microcline), chlorite, kaolinite, illite, muscovite, with traces of $14 \AA$ smectite and illite/smectite randomly interstratified structure. In strongly acidic solution, according to XRD, smectite is altered (14 $\AA$ peak vanishing), chlorite being also partly reduced, while kaolinite is stable. Carbonates are not involved in reactions. In basic solution, smectite was less affected, but chlorite peaks indicate structural transformation. The shape and broadening of $10 \AA$ peak shows changes in illite and illite/smectite interstratified structures. Altogether, mineralogical changes indicate reactions which lead to fines mobilization.

Based on experimental work, in the case injection with $\mathrm{pH} 2.5$ and $\mathrm{pH} 9.5$, there has been a rapid and substantial reduction in permeability as an average $38.54 \%$ and $73.72 \%$ for acidic and basic solutions respectively. The results confirmed that the reason of the reduction in permeability is due to the non-swelling clay minerals which are dispersed and migrated during the changes in $\mathrm{pH}$, salinity and time. Novelty of these experiments is the tracking of changes in mineralogy by Rietveld refinement on XRD, coupled with diagnostic clay mineral investigation.
\end{abstract}

Keywords: water injection, clay minerals, XRD, fines migration, permeability, $\mathrm{pH}$

\section{Introduction}

Sandstones are porous siliciclastic, important oil and gas reservoir rocks which may be deposited in many different depositional environments and have high variability in texture and composition. Most sandstone rocks contain clay minerals, which have an important role in controlling the reservoir characteristics, such as permeability, water saturation, capillary pressure and wettability. Clay minerals might cause a sever permeability reduction, due to their tendency to migrate and hence, plug interconnecting pore throats. ${ }^{1}$ Fine-grained clay minerals are present in most sandstones and some carbonates formation, they are not held in place by the confining pressure and are free to move when contact with fresh or low salinity-water occurs. The types, proportions and distribution patterns (cement or pore filling) of clay minerals in sandstones have a significant impact on petrophysical properties and overall reservoir qualities. ${ }^{2-3}$ The presence of both detrital and authigenic clay minerals commonly have a negative impact on the reservoir quality of sandstone reservoirs by reducing permeability. ${ }^{4}$ Clay minerals trapped at the small pore throats will lead to an increase of fluid pressure to maintain the flow, as a result decreasing the overall permeability of the porous system. The majority of hydrocarbon producing formations contain clay minerals, and the reaction of water (low salinity fluids) with these clay minerals tends to cause fines migration and clay swelling. ${ }^{5}$ The porous medium of sandstone can be represented as a network, consisting of pores connected with each other by throats or narrower pore channels. The presence of clay minerals as dispersed matrix in the pore spaces and permeability channels of the reservoir rock reduces pore throat size and overall permeability. Authigenic kaolinite is the most common clay mineral in sandstone reservoirs. And mostly forms pore- filling flakes. ${ }^{6-7}$

From the viewpoint of petroleum engineers, the two most important properties of a reservoir rock are porosity and permeability. Permeability is controlled by interconnected porosity and composition of fluid, like salinity and $\mathrm{pH} .^{8-16}$ If any physical or chemical processes affect interconnected porosity, there will be a change in permeability. Reduction of permeability in the case of reservoir rocks is commonly known as formation damage in the petroleum reservoirs and occurs in different stages of reservoir development from drilling to extraction. ${ }^{17}$ 
Formation damage is defined as the reduction in the natural capability of a reservoir to produce its fluids, and is identified by a reduction in rock permeability and reduced well performance. ${ }^{18}$ Formation damage has been a topic of research for more than five decades, and many papers and researches have been published on the subject. The reason for such intense interest is because of great financial gains from increasing reservoir productivity. The obvious way to increase productivity is to minimize damage, and thus a comprehensive understanding of the modes of formation damage is needed. The extent of formation damage depends on fluid properties, rock properties and rock-fluid interaction. Formation damage adversely affects production of petroleum reservoirs by reducing the permeability of the near wellbore region. A small zone of reduced permeability due to migration and retention of fine particles may cause significant reduction the productivity of a petroleum reservoir. ${ }^{12,19-25}$ Therefore, understanding the mechanism of formation damage and the factors controlling its severity are vital for improving the accuracy of reservoir evaluation and the efficiency of reservoir production. As stated by Ohen and Civan, ${ }^{26}$ Civan and Xinghui, ${ }^{27}$ and Musharova et al. ${ }^{28}$ formation damage is an undesirable phenomenon encountered in almost every phase of hydrocarbon production. The presence of clay minerals is connected to formation damage, considered one of the most important factors of permeability reduction. ${ }^{26} \mathrm{~A}$ number of other authors have addressed the various mechanisms responsible for formation damage, including rock mineralogical composition, quality of injected fluids, particle invasion, formation fine migration, chemical precipitation, swelling and flocculation of clay minerals and pore deformation or collapse. ${ }^{29-32}$ While there are many potential causes for formation damage, our focus is on damage due to interaction between the clay minerals and fluid injected into the reservoir rock. These interactions include: clay minerals swelling, clay minerals deflocculation, dispersion and migration of fine particles. ${ }^{32-33}$

Since the existing clay minerals within the rock matrix can have undesirable effects during water injection process, it is necessary to investigate the type and amount of existing clay minerals via core samples. The most important types of clay minerals regarding permeability reduction in most sandstone reservoirs are kaolinite, smectite, illite, chlorite and fine grained non-clay minerals. The reaction of water filtrates with the clay minerals of the reservoir can reduce the permeability either considerably or negligibly depending on the type of existing clay minerals. ${ }^{34}$ Research on the effect of clay minerals on sandstone permeability has been conducted for more than five decades, but still the presence of clay minerals in reservoir rocks presents a challenge for petroleum production. ${ }^{2}$ Clay minerals may be present in the form of detrital matrix or part of rock fragments known as "allogenic clays" and as replacements or cements called "authigenic clays". The type of clay minerals and their amount and distribution in sandstones has a significant impact on porosity, permeability and rate of production. Authigenic clay minerals have more impact on formation damage because of their direct vulnerability to pore fluids than detrital clay minerals which is tightly packed in the rock matrix. ${ }^{35}$ Authigenic clay minerals occur as pore linings, pore fillings, pseudomorphic replacements and fracture fillings, they have a major control on reservoir quality. ${ }^{6-7}$ Authigenic clay minerals strongly influence and control the sandstone reservoir characteristics at different stages of the diagenetic history. ${ }^{36}$ Different clay mineral cements can have different effects on permeability (e.g. kaolinite produces higher formation damage) than illite. ${ }^{37}$ The widely accepted model of in-situ clay induced formation damage supposes that the permeability reduction occurs due to release of clay particles from pore walls and their subsequent redeposition downstream in the pore throats, which presumably have smaller diameters than the pores.$^{38}$ Morphology, amount and distribution pattern of clay minerals also have significant influences on sandstone reservoir performance in terms of porosity and permeability. ${ }^{39}$

According to Mungan, ${ }^{40}$ clay damage depends on (1) the type and amount of the exchangeable cations, and (2) the layered structure. Reduction of permeability due to clay minerals can also be classified to swelling and non- swelling clays. Kaolinite is non-swelling clay mineral easily dispersed and migrated. Smectite has a large cation (base) exchange capacity of 90 to $150 \mathrm{meq} / 100 \mathrm{~g}$, and will readily adsorb $\mathrm{Na}^{+}$, leading to a high degree of swelling and dispersion. Illites combine the worst characteristics of the dispersible and the swelling clay minerals, hence they are the most difficult to stabilize. Interstratified clay minerals, especially illite- smectite and kaolinitesmectite could produce damage processes problematic to model, since they combine swelling and dispersion. In case of changing chemical environment of the reservoir as a result of water injection, clay minerals are exposed to dispersion and migration. In oil fields water injection is a common method used for pressure maintenance and enhanced oil recovery. The physicochemical factors related to clay induced formation damage include fluid temperature, $\mathrm{pH}$, salinity and flow rate, clay mineralogy. Salinity and $\mathrm{pH}$ affects stability, while flow rate will affect transport of clay particles in the sandstone reservoir.

Salinity of fluids usually has an impact on clay mineral behavior leading to formation damage. Interstratified and smectite clays can swell with changing ionic conditions and eventually disperse and migrate with the flowing fluids, swelling alone reduces the effective area for flow and thus they can cause a reduction in permeability. Kaolinites and illites are (non-swelling) clays that tend to detach from the rock surface and migrate when the colloidal conditions are conductive for release. Migrating fine particles can get trapped in pore throats, thus causing a reduction in permeability. Usually, the reduction of permeability occurs when injected water is less saline than formation water. ${ }^{2}$

A number of studies in the past have addressed the subject of formation damage due to non- swelling clays. Their comprehensive studies demonstrate the role of $\mathrm{pH}$, ionic exchange, and brine concentration on the release or detachment of migrating clays from pore surfaces and subsequent permeability reduction of the porous medium. , $^{8,1322,41}$ Migration of clay minerals influenced by $\mathrm{pH}$, generally clay dispersion is affected by alkaline solution with a $\mathrm{pH}$ of greater than 7.0 making clay minerals more mobile. ${ }^{37}$ Once a clay mineral is dispersed its particles become free to move and may cause plugging of the pore throats.

This paper describes the influence of $\mathrm{pH}$, salinity and time on the main petrophysical properties (porosity and permeability) of the reservoir sandstones. The main objectives of this study are the understanding the linkage between clay minerals and petrophysical properties of sandstone reservoirs, to describe the effect of clay minerals on the reservoir quality. Also based on the analyses carried out, the influence of clay minerals, different $\mathrm{pH}$ values, salt concentration and time on permeability reduction is investigated. As a new approach, the role of flow direction is discussed, by observing the change in quantitative mineralogy with the application of Rietveld refinement. This approach has not been discussed in earlier papers, but it has high importance in 
describing and quantifying formation fines migration.

\section{Materials and methods}

Two synthetic sandstone core plugs collected from the Institute of Petroleum and Natural Gas, University of Miskolc. These are A-13-A and A- 14- B shown in Figure 1.

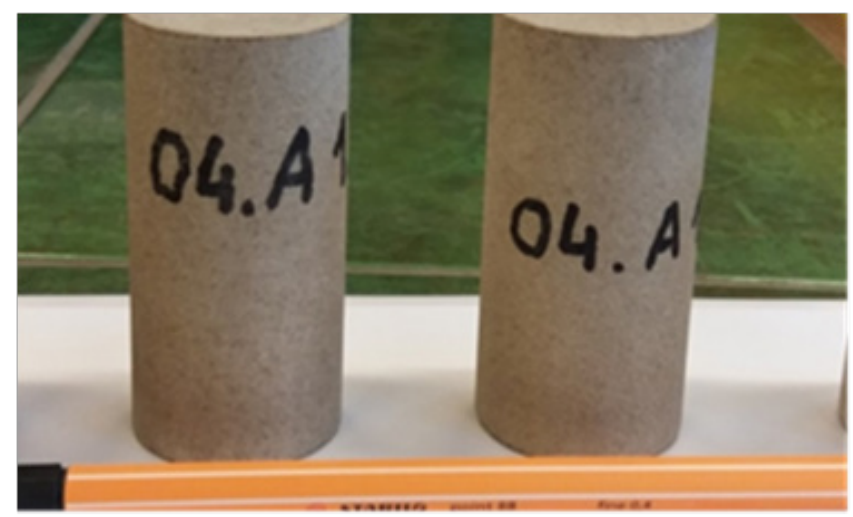

Figure I Core plugs.

The core samples were subjected to X-ray powder diffraction (XRPD) and scanning electron microscopy with energy dispersive spectrometry (SEM+EDS) at the Institute of Geology and Mineralogy, University of Miskolc to identify the mineralogical composition and clay minerals and to determine the site of clay minerals accumulation within the cores.

The XRD measurements were done on Bruker D8 Advance X-ray diffractometer $(\mathrm{Cu}-\mathrm{K} \alpha$ source $)$. The instrument is equipped with vertical theta/theta goniometer and Göbel mirror for parallel beam geometry. To determine the amount and type of bulk and clay minerals, a grinding technique was used to produce powders free of grains coarser than $10 \mu \mathrm{m}$. The clay mineral fraction $<2 \mu \mathrm{m}$ was obtained by sedimentation and centrifugation (42)(Brown and Brindley, 1980), thus the clay mineral sample of higher purity could be obtained. The XRD of the clay mineral fraction was measured on oriented samples. The types of clay minerals were identified from measurements in air-dried (AD) state and by the help of treatment methods such as, ethylene glycolation (EG) and heating up to 350 and $550^{\circ} \mathrm{C}$, according to Thorez, ${ }^{43}$ Ransom et al. ${ }^{44}$ Moore, ${ }^{45}$ and Fonseca et al $^{46}$ The ethylene glycolated samples are obtained by applying solvation over $12 \mathrm{~h}$ at $60^{\circ} \mathrm{C}$ to the oriented air-dried samples. Heated samples are obtained by heating samples up to $350^{\circ} \mathrm{C}$ and $550^{\circ} \mathrm{C}$ at $10^{\circ} \mathrm{C} / \mathrm{min}$ linear heating in air, according to the standard procedure of Thorez. ${ }^{43}$ The identification of the components was done by Search/Match in the Diffrac Plus Eva software of Bruker,

Table I Composition of the saline solutions from ICDD PDF2 database. The quantitative evaluation of the results was done using TOPAS4 software, with Rietveld profile fitting. It is widely used method of identification and quantification of clay minerals in sandstones or other rock type. Amorphous hump method, by combining Rietveld refinement and single peak fitting, was applied to model the amorphous humps as abroad peak was used to determine the percentage of amorphous content.

SEM+EDS were performed on polished sections obtained from the core plug after epoxy resin cementation under vacuum conditions, so that open pore spaces would be filled and clay cement immobilized, enabling us to observe original texture in polished sections. Backscattered electron (BSE) images were obtained on a Jeol JXA 8600 Superprobe instrument (W filament, $20 \mathrm{kV}$ acceleration voltage and 20 nA probe current, carbon coating). Energy dispersed spectroscopy (EDS) spectra were recorded in standard less mode (RemiX Si-drift detector, $\mathrm{C}-\mathrm{U}$ detection range) with $60 \mathrm{sec}$ collecting time (15\% dead time), quantified by PAP correction.

Petrophysical analysis and core flooding were conducted at the Research Institute of Applied Earth Science, University of Miskolc. The selected cores used in the study reported here are around 3.7 $\mathrm{cm}$ by $7.0 \mathrm{~cm}$. Prior to permeability testing, the core samples were vacuum-dried and then were vacuum-saturated using $5 \mathrm{wt} \% \mathrm{NaCl}$ brine. Petrophysical analyses included determining the porosity by He-porosimeter (Multi Pycnometer with Analogic Champion Series system). Then the saturated cores are placed in a Hassler- type core holder to start the injection process. A sleeve pressure (confining pressure) $25 \mathrm{bar} / \mathrm{cm}^{2}$ was applied. No back pressure was required during the testing conducted at ambient condition, after that the absolute and core flood permeability was measured. The following experiments were designed to estimate the possible reduction in permeability and the relative contributions of the different clays to the damage:

- using $\mathrm{NaCl} 5 \mathrm{wt} \%$ brine to determine the initial permeability of the selected sandstone core plugs at room temperature and atmospheric pressure with at a flow rate $200 \mathrm{ml} / \mathrm{hr}$

- multistep experiments for 6 and 8 hours at pH 2.5 (set with $\mathrm{HCl}$, $0.01 \mathrm{wt} \% \mathrm{NaCl}$ ) at room temperature and atmospheric pressure at a constant volumetric flow rate $100 \mathrm{ml} / \mathrm{hr}$, first the experiment run for $6 \mathrm{hrs}$ in one working day and then at the next day the second step started for $8 \mathrm{hrs}$.

- multistep experiments for 6 and 8 hours at pH 9.5 (set with $\mathrm{KOH}$, $0.01 \mathrm{wt} \% \mathrm{NaCl}$ ) at room temperature and atmospheric pressure at a constant volumetric flow rate $100 \mathrm{ml} / \mathrm{hr}$, first the experiment run for $6 \mathrm{hrs}$ in one working day and then at the next day the second step started for $8 \mathrm{hrs}$ on the same core.

Composition of saline solutions of sodium chloride prepared with different $\mathrm{pH}$ (strong acid $2.5 \mathrm{pH}$ and alkaline $\mathrm{pH}$ 9.5) are shown in Table 1.

\begin{tabular}{llllll}
\hline Type of Solution & $\mathbf{H C l} \mathbf{1 0} \mathbf{\%}(\mathbf{m l})$ & $\mathbf{K O H} \mathbf{1 M}(\mathbf{m l})$ & $\mathbf{N a C l}(\mathbf{g})$ & Distilled water $(\mathbf{L})$ & $\mathbf{p H}$ \\
\hline Acidic & 0.2 & $\ldots \ldots .$. & 0.4 & 3.2 & 2.5 \\
Basic & $\ldots \ldots \ldots$ & 0.6 & 0.4 & 3.2 & 9.5 \\
\hline
\end{tabular}




\section{Results and discussion}

\section{XRD and SEM- EDS interpretation}

XRD was used to identify and quantify minerals. The identified clay minerals in the bulk sample are: kaolinite, illite and chlorite (Figure 2).

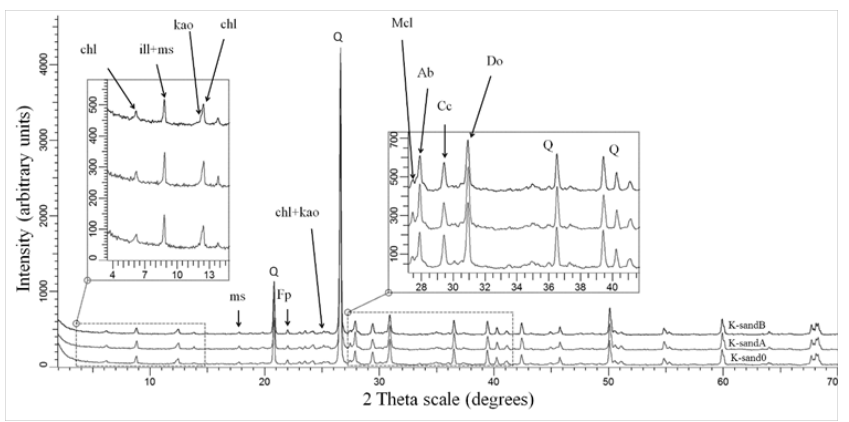

Figure 2 Bulk Mineralogy of starting (K-sand0), acidic flooded (K-sandA) and basic flooded (K-sandB) samples.
Smectite was detected only by diagnostic clay mineral investigation, by ethylene-glycol swelling. The amount of smectite is estimated below $1 \mathrm{wt} \%$, not possible to quantify from the bulk powder because of the chlorite presence. X- ray diffraction powder test for the bulk samples revealed that the core plugs are mainly composed of quartz, with clay minerals $<10 \mathrm{wt} \%$ (Table 2 ). XRD run on the bulk powders after flooding tests revealed small differences in all minerals compared to the starting sample. For these differences we have to account for mineralogical inhomogeneity between core plugs, but also for fines migration as a possible result. In order to verify this theory, bulk powders were prepared from top and bottom sections of flooded cores. The largest difference of top to bottom sections was observed for illite, as enrichment in the bottom section, in accordance with particle migration theory. Also, a large difference between muscovite and illite is observed between original and flooded samples. Separation of muscovite from illite in quantification is primarily based on the peak broadening of 10,5 and $\sim 4.5 \AA$ peaks. Thus, in flooded samples we have a reduction of peak broadening for these peaks, which may be the effect of illite and muscovite ordering. An ordering of illite and muscovite structures may be related to the presence of swelling layers in low number, insignificant in oriented specimens. When these swelling layers are collapsed by the interaction with saline solution, the broadening of $10 \AA$ peak will be reduced.

Table 2 XRD results (bulk powder) on applied sandstone core plugs (weight percent)

\begin{tabular}{|c|c|c|c|c|c|c|c|c|c|c|c|}
\hline \multirow[b]{2}{*}{ Core ID } & \multirow[b]{2}{*}{ 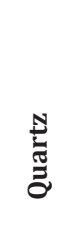 } & \multicolumn{4}{|c|}{ Non- Clay Minerals } & \multirow[b]{2}{*}{ 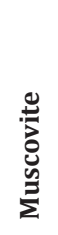 } & \multicolumn{4}{|c|}{ Clay Content } & \multirow{2}{*}{ 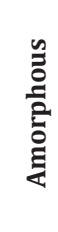 } \\
\hline & & 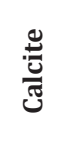 & 苞 & 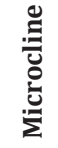 & 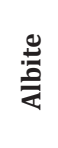 & & 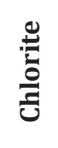 & 兰 & 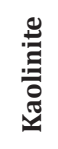 & 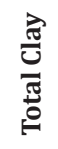 & \\
\hline K-sand0 & 55.0 & 4.1 & 8.8 & 2.7 & 8.3 & 1.5 & 2.4 & 4.0 & 1.1 & 7.5 & 12.0 \\
\hline $\begin{array}{c}\text { A13- B } \\
\text { Top }\end{array}$ & 54.5 & 3.6 & 8.6 & 3.0 & 7.6 & 4.6 & 2.4 & 1.7 & 1.9 & 6.0 & 12.0 \\
\hline $\begin{array}{l}\text { A13-B } \\
\text { Bottom }\end{array}$ & 54.3 & 3.8 & 8.0 & 3.4 & 8.9 & 3.1 & 2.8 & 2.6 & 1.5 & 6.9 & 11.5 \\
\hline $\begin{array}{c}\text { A13-A } \\
\text { Top }\end{array}$ & 55.8 & 4.0 & 7.7 & 2.8 & 8.8 & 3.5 & 2.1 & 2.5 & 1.8 & 6.4 & 11.0 \\
\hline $\begin{array}{l}\text { A13-A } \\
\text { Bottom }\end{array}$ & 55.5 & 3.6 & 8.5 & 3.0 & 8.4 & 2.8 & 1.7 & 4.7 & 1.9 & 8.3 & 10.0 \\
\hline
\end{tabular}

Carbonates were not affected by acidic fluid, as shown by quantitative XRD results, but the mobilisation of clay particles is evidenced by the variation in the total clay content (Table 2), always higher in the bottom section of the core plugs. Some amount of clay minerals was even flushed from the core plugs, since the total clay in K-sand0 is higher, than in the core plugs. The $8.3 \mathrm{wt} \%$ total clay in A13-A Bottom samples is connected with the lower amount of amorphous fraction, suggesting that small part of amorphous material is actually X-ray amorphous clay mineral(s). For instance, X-ray amorphous illite-smectite interstratified phases could gain ordering by collapse of swelling layer and act as nanocrystalline illite particles.

The small peak at $17 \AA ̊$ for K-sand0 sample after ethylene glycolation indicates the peak of smectite, which has a very low amount in the bulk sample. The flooded samples did not show the presence of swelling clay minerals (Figure 3), which is a direct effect of salinity, since it was the same in both acidic and basic solution.

The diffraction peak of $14 \AA$ remains unchanged after ethylene glycolation and heating to $350^{\circ} \mathrm{C}$, but has an increase of intensity after $550^{\circ} \mathrm{C}$ heating, indicated that there is Mg-rich chlorite in the samples. A $10 \AA$ diffraction peak in air dried sample not altered at various treatments indicates that there is illite, dioctahedral according to (060) peak position. The diffraction peak of $7 \AA$ peak does not changes at ethylene glycolation and collapsed at $550^{\circ} \mathrm{C}$ indicating the presence of kaolinite.

The BSE images have been taken by SEM of K-sand0 sample to analyse the distribution patterns of clay minerals. The black areas of BSE images constitute open pore spaces filled with epoxy resin (15- 
$20 \mathrm{~V} / \mathrm{V} \%)$. The large pores among quartz grains form a connected flow path, they would account for the majority of the flow through the sample. Quartz grains make up majority of the samples more, than $50 \%$ which is supported by XRD quantification. The samples consist predominately of quartz grains with grain size ranging approximately between $20 \mu \mathrm{m}-500 \mu \mathrm{m}$, with various shapes from sub-rounded to angular (Figure 4).
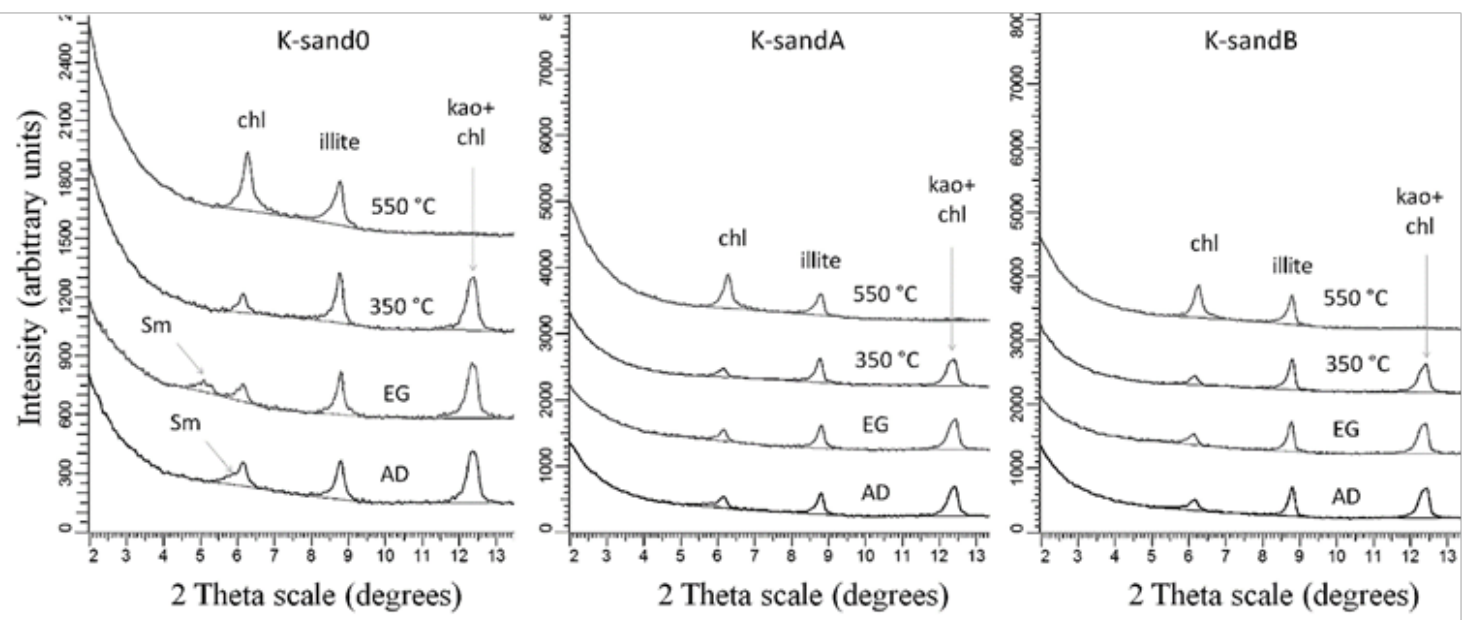

Figure 3 Clay mineralogy K-sand0;A-I 3-A (acidic) and A-3-B (basic) ( $\mathrm{Sm}=$ smectite, chl=chlorite, kao=kaolinite,AD=air dired, EG=ethylene glycol solvated).
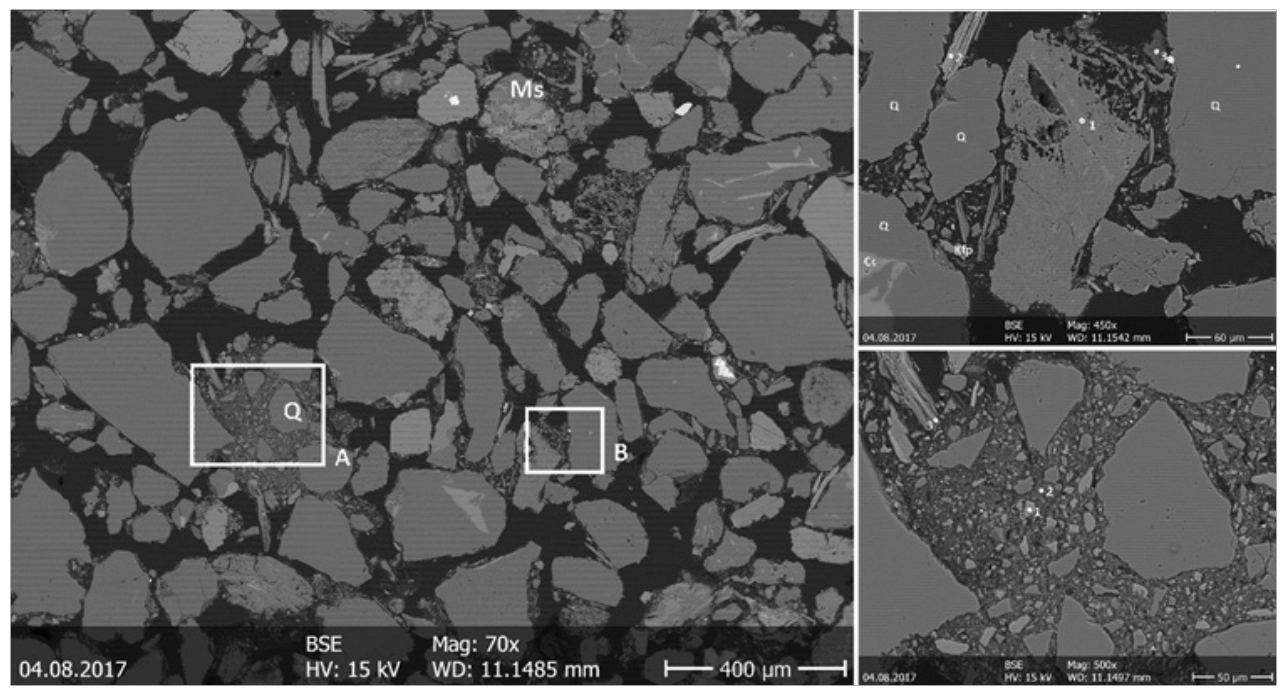

Figure 4 BSE image with a larger view on $\mathrm{K}$-sand0 texture $(\mathrm{Q}=$ quartz, $\mathrm{Ms}=$ muscovite). The outlined sections are shown with higher magnification to illustrate more compacted clay cement $(\mathrm{A})$ and more porous-loose filling $(\mathrm{B})$.

We also observed the presence of albite and microcline, ranging between $50 \mu \mathrm{m}$ to $200 \mu \mathrm{m}$ with angular and tabular shapes distributed between the quartz grains. K-feldspar grains $20 \mu \mathrm{m}$ to $30 \mu \mathrm{m}$ with lamellar shapes also may fill the pores between the quartz grains. Carbonate cement was observed between other flakes and the quartz grains, which develops microporosity and increased porosity. Other non-clay minerals are muscovite and biotite, their grain size ranges between $30-60 \mu \mathrm{m}$ with flaky shapes between the quartz grains. The clay minerals observed include kaolinite, illite, chlorite, mixed growth of illite and chlorite and non-clay minerals such as quartz, some pyrite, calcite, dolomite, albite and siderite. SEM+EDS analysis was applied to determine the cations of clay minerals, grain sizes/shapes and chemical composition for the different minerals. A peculiar carbonate phase with $\mathrm{Ca}-\mathrm{Fe}-\mathrm{Mg}$ cations, not detected by XRD, was observed by SEM and EDS analysis (Figure 5a). Albite ranges between $100-150 \mu \mathrm{m}$ present as coarse grains together with quartz. Because carbonates (1) were developed just inside chlorite flakes, and not the tabular muscovite (3), we assume that $\mathrm{Fe}$ and $\mathrm{Mg}$ was extracted from chlorite due to alteration by $\mathrm{CO}_{2}$ rich fluids. Muscovite grains ranges around $100 \mu \mathrm{m}$, clinochlore flakes ranges between 30 $50 \mu \mathrm{m}$ with lamellar shape. 
Illite, chlorite and kaolinite are observed as dominant pore filling clay minerals with diameters ranging from $0.5 \mu \mathrm{m}$ to $10 \mu \mathrm{m}$ and thickness ranging from $0.1 \mu \mathrm{m}$ to $1.0 \mu \mathrm{m}$, filled the pores between the quartz grains (Figure 5b).

Muscovite (1) appears in flaky shapes between the quartz grains, with alteration marks, like exfoliation of lamellas. Kaolinite (2) particles are located in between the cleavage plane of tabular muscovite grains (3) as micrometric platy crystals. Angular K-feldspar (4) of 10-50 $\mu \mathrm{m}$, carbonates with high content of $\mathrm{Mg}(5)$ and illite with small particles (6) are also present. Kaolinite aggregates of $<10 \mu \mathrm{m}$ sizes are also developed inside pore volume (7). Quartz grains with $>400 \mu \mathrm{m}$ and angular to sub-rounded shape are characteristic. We were not able to distinguish each individual particle of clay minerals because their size is below the resolution of the applied SEM.

Clay minerals of the observed distribution pattern might reduce permeability by potential fines mobilisation. ${ }^{47}$ Whereas small illite, chlorite or kaolinite fine particles in intergranular pores might be mobilised, larger mica, muscovite and K-feldspar grains can be observed in the tested samples that are presumably not mobile. Clay minerals are observed concentrated in some pores and not in others.

\section{Interpretation of initial permeability and core flood}

Petrophysical analysis were focused on the effect fluid-clay mineral interaction observed by porosity and liquid permeability changes. Most laboratory experiments on sandstone core plugs use an injection of $\mathrm{NaCl}(5 \mathrm{wt} \%)$ brine most frequently of basic $\mathrm{pH}$ to simulate pore fluids occurring in reservoir conditions.

Initial permeability for core plugs was measured with Hasslertype core holder after they are fully saturated in a formation brine was between 409 and $420 \mathrm{mD}$. Then the core flood experiments are carried out to investigate the influence of the selected solution (acidic and alkaline), the obtained result shows that a drastic reduction on permeability at both $\mathrm{pH}$ values. Permeability with acidic solution is reduced slightly by $5.92 \%$ at $\mathrm{pH} 2.5$ after 6 hours flooding while after 8 hours drops abruptly to $38.54 \%$ of it is original permeability (Figure 6: a,b) respectively. On the other hand, with basic-alkaline solution, permeability dropped slowly about $18.75 \%$ at $\mathrm{pH} 9.5$ after 6 hours flooding and after 8 hours the reduction of permeability rapidly changed to $73.72 \%$ (Figure $6: \mathrm{c}, \mathrm{d}$ ) respectively. The formation damage is quite significant but it is not drastic. The results show that increasing $\mathrm{pH}$ (or alkalinity) of the solution causes more significant formation damage.

The permeability reduction occurred due to the release of fine grains (non-clay minerals) and clay particles from pore walls and subsequent re-deposition downstream in pore throats, which are plugged by particles otherwise dispersed in the original sandstone structure. According to X-ray powder diffraction analysis the migratory fines are mainly illite, kaolinite, and chlorite. Besides clay particles quartz, dolomite, calcite, albite and amorphous materials are assumed to contribute in formation damage. Kaolinite and illite particles might reduce permeability by fine migration. ${ }^{47}$

Releasing of fine clay particles from pore volumes can be explained by the cation exchange of surface adsorbed ions, reactions occurring during saturation of the core plugs with high acidic $(\mathrm{HCl})$ and high basic $(\mathrm{KOH})$ solutions. XRD quantitative analysis shows that the direction of flood is another factor which reduces the degree of permeability. The percentage of fine grained clay particles changes from upstream to the downstream, due to the direction of flow and migration of non-swelling clay particles and non-clay particles, which causes a sharp decline in permeability shown in Table 3 . The loss of permeability in our case may be attributed to clay and fine particle migration rather than clay swelling in pore space, given the low amount of swelling clay minerals determined by XRD (Figure 3 ). Accordingly, the degree of damage is believed to be a function of the $\mathrm{pH}$ on the first order and time on the second order (Table 3). The large difference of permeability for different $\mathrm{pH}$ arises from the amount of clay minerals, especially kaolinite that can be mobilized by a given fluid composition. The damaging mechanism reflected by permeability reduction is that of deflocculated clay particles blocking pore throats or closing pores by coagulation..$^{10,12}$ The higher permeability of acidic flooding (A-13-A core) is in good agreement with earlier reports on effect of $\mathrm{pH}$, several studies showed that dispersion of clay minerals was minimized at low $\mathrm{pH}^{8,14}$

Table 3 Permeability and porosity of sandstone core plugs. D: diameter $(\mathrm{cm})$; L: length $(\mathrm{cm})$, A: cross- sectional area $\left(\mathrm{cm}^{2}\right)$, k: permeability $(\mathrm{mD})$; Dr: Damage ratio $=100-\left(\mathrm{k}_{\mathrm{F}} * 100 / \mathrm{k}_{1}\right)$

\begin{tabular}{|c|c|c|c|c|c|c|c|c|c|}
\hline \multirow{2}{*}{ Core ID } & \multirow{2}{*}{ D. $(\mathrm{cm})$} & \multirow{2}{*}{ L. $(\mathrm{cm})$} & \multirow{2}{*}{$\mathbf{A}\left(\mathrm{cm}^{2}\right)$} & \multirow{2}{*}{$\begin{array}{l}\text { Porosity } \\
\phi \%\end{array}$} & \multirow{2}{*}{$\mathbf{k}_{\mathrm{i}}(\mathrm{mD})$} & \multirow{2}{*}{$\begin{array}{l}\text { k@ @ } 6 \mathrm{hrs} \\
\text { (mD) }\end{array}$} & \multirow{2}{*}{$\begin{array}{l}\text { k @ 8hrs } \\
\text { (mD) }\end{array}$} & \multicolumn{2}{|c|}{$\mathbf{k} \%$ reduction (Dr) } \\
\hline & & & & & & & & @ 6h & $@ 8 h$ \\
\hline A-13-A & 3.724 & 7.065 & 10.894 & 0.2231 & 409.364 & 385.144 & 251.588 & 5.92 & 38.54 \\
\hline A-13-B & 3.715 & 7.155 & 10.839 & 0.1445 & 416.546 & 338.460 & 109.459 & 18.75 & 73.72 \\
\hline
\end{tabular}

Evolution of formation damage in time results in even more drastic permeability reduction for basic solution flooding (A-13B), than acidic one, also indicating that fluid $\mathrm{pH}$ is the main factor influencing clay and fine particle migration.

\section{Interpreting the effect of $\mathrm{pH}$ and salinity in terms of mineralogical and permeability changes}

This interpretation leads to several new observations, not discussed extensively in related literature.

Among the different minerals identified by XRD and SEM we found several which are usually responsible in formation damage. Clay minerals - kaolinite, illite and also chlorite - are located in pores as we observed by SEM+EDS. Additionally, carbonates, feldspars but also quartz were observed as potential fines which might reduce permeability by migration. ${ }^{47}$ Whereas small illite, chlorite or kaolinite particles in intergranular pores might be mobilized, larger mica, muscovite and K-feldspar grains were observed in the tested samples that are presumably not mobile.

Formation fines mobilisation in general was observed by the quantitative data obtained with Rietveld refinement (Table 2), since most of the minerals in the starting sample have lower amounts in the flooded samples, except for quartz and albite. The variation 
in muscovite and illite content has been linked to the presence and collapse of swelling layers in low numbers in the illite and/or muscovite structures. This was observed by clay mineral diagnostic XRD investigations, observing a high angle shoulder at $\sim 10.1 \AA$ of the illite peak (Figure 3, K-sand0), produced by illite-smectite or muscovite-smectite interstratified phase. The shoulder of illite peak is not observed in the acidic and basic flooded samples, leading to the conclusion that swelling layers collapsed. By collapse a micalike structure is created, leading to the sharpening and increase in intensity of illite peak. The same collapse occurred for the smectite, not evidenced by EG treatment in flooded samples.

The loss of permeability in sandstone core plugs can be attributed either to clay swelling in the rock pores or due to clay particle migration. Based on diagnostic clay mineral investigation, we can rule out the impact of swelling clay minerals, due to their trace amount. Mohan et al. ${ }^{17}$ showed that the damage due to kaolinite does not become apparent till high pH (higher than 9) in Stevens sandstone. Accordingly, our result proved that permeability is reduced significantly at high $\mathrm{pH}$, becomes more apparent at $\mathrm{pH}>9$. The critical flocculation concentration of illites at $\mathrm{pH} 6.0$ is $0.025 \mathrm{M}$ and is expected to be lower at $\mathrm{pH} 2.0$, which they attributed to collapsing swelling components in the illite structure, like illite-smectite interstratification. ${ }^{17}$ The data in Table 3 also shows a higher mobilisation of illite from upper to bottom section of the acidic fluid treated core plug. A similar process may be partly responsible in our experiments, with smectite layers present in illite in such a low number, that ethylene-glycolation could not evidence it.
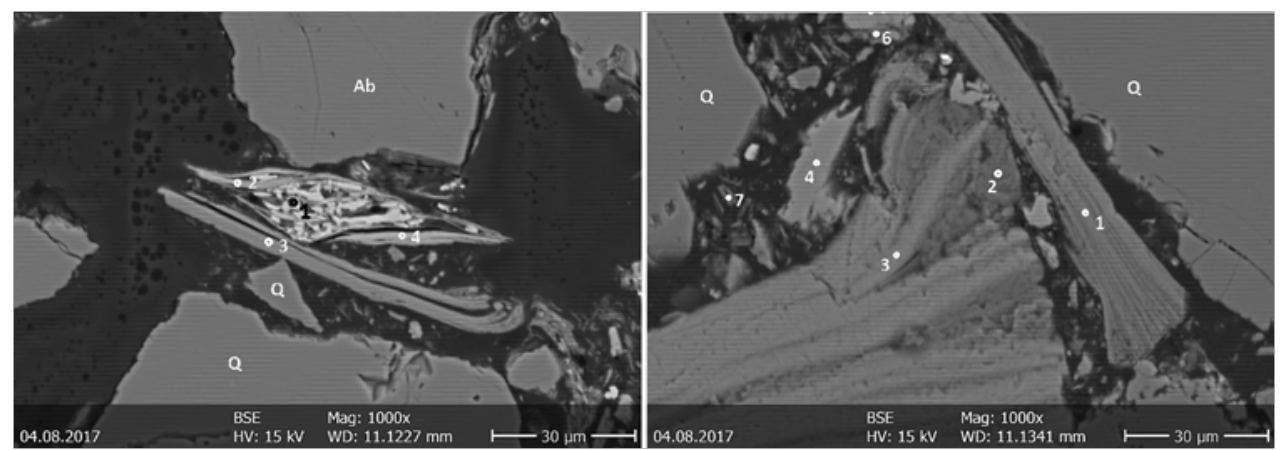

Figure 5 BSE image of an untested sandstone core plug, (a) micrometric $\mathrm{Ca}-\mathrm{Fe}-\mathrm{Mg}$ carbonate crystals (I) in chlorite (2, 4) (3-muscovite, Q-quartz, Abalbite); (b) fine grained pore filling material (I, 3-muscovite, 2, 7-kaolinite, 4-K-feldspar, 5-calcite, 6-illite, Q-quartz).
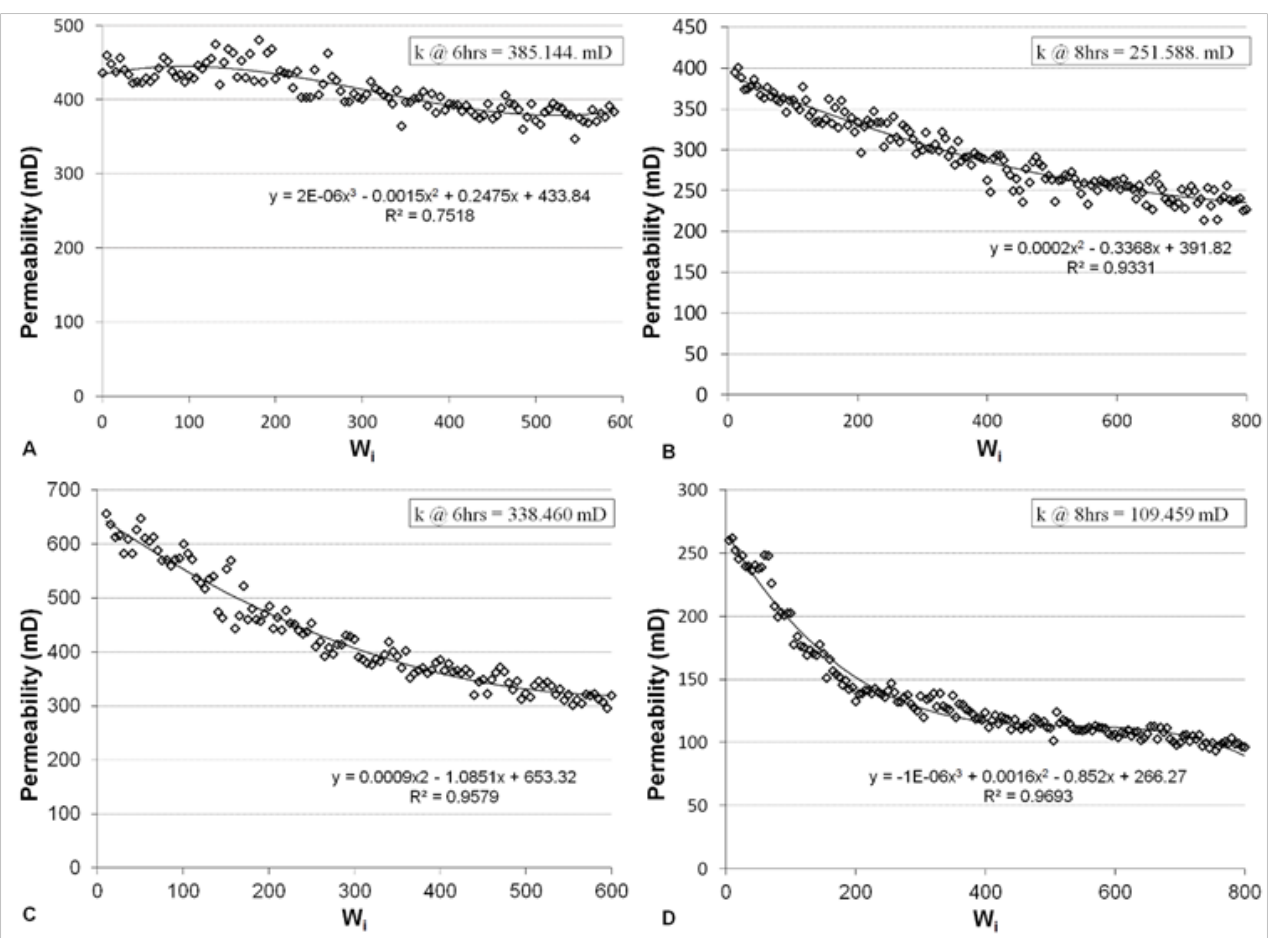

Figure 6 Permeability reduction of damaged core plugs ( $A$ and B damaging after acidic flooding, C and D damaging after basic flooding). 
The degree of damage is believed to be a function of the migrated amount of clay minerals (especially kaolinite), as a result of interactions with cations in the solution. Clay deflocculating and coagulation are the main reasons for damage in our experiments, are directly controlled by ions in solution. Based on the results obtained by XRD quantitative analysis proved that migration of fine particles of clay minerals and non- clay minerals are the main source for reduction in permeability in both core plugs.

The result of experiments listed in Table 2 shows that permeability of the selected core plugs was damaged substantially, decreased around $38 \%(\mathrm{~V} / \mathrm{V})$ with acidic and $73 \%(\mathrm{~V} / \mathrm{V})$ with alkaline at 8 hours' time period, and in a different extent by the change in $\mathrm{pH}$. The rise of $\mathrm{pH}$ is believed to increase the release of fine clay particles and cause a significant reduction in permeability. Valdya and Fogler ${ }^{14}$ reported small variations in permeability for $\mathrm{pH}$ up to 9.0 and found that permeability impairment starts at $\mathrm{pH}>9.0$, while for $\mathrm{pH}>11$, they observed a rapid and drastic reduce in permeability. Different showed that dispersion of clay minerals was minimized at low $\mathrm{pH}^{8,14}$ We revealed that a sharp decline in permeability occurs at high $\mathrm{pH}$. Generally, the results show that these cores get damaged substantially by change in $\mathrm{pH}$. The degree of damage is believed to be a function of the amount of clay minerals that have been migrated.

Another potentially significant damaging mechanism of permeability reduction in these cores is a function of time, we observed increasing duration of flooding causes permeability impairment more significant.

\section{Conclusion}

The primary cause of permeability reduction is the blocking of pore passages by dispersed particles. The mineralogical composition of the sandstone core plugs at both sides prove the impact of the flow direction on mineralogical composition responsible for formation damage. The phenomenon of clay dispersion is clear evidence of the damage in the selected samples.

Since the prevailing clay minerals are kaolinite, illite and chlorite, migration rather than swelling is the process behind permeability reduction. The degree of formation damage is believed to be a function of the amount of non- swelling clay minerals that have been migrated.

The migration of fines within porous media has been recognized as a source of potentially sever permeability impairment in sandstone reservoirs. Non- swelling clay minerals contribute significantly to permeability reduction in both high and low $\mathrm{pH}$ ranges. In selected samples there are only traces of swelling clay minerals as revealed by XRD, they had no influence on permeability impairment.

Despite sample inhomogeneity shown by Rietveld refinement, the effect of formation fines migrations was proven, impacting in total clay mineral amounts.

The percentage of reduction in permeability with basic solution $(\mathrm{pH}$ 9.5) is more significant than acidic solution ( $\mathrm{pH} 2.5$ ). In both cases time and flow direction are important factors which are causing the drop in permeability.

\section{References}

1. Afrough A, Zamiri MS, Romero-Zerón L, et al. Magnetic-resonance imaging of fines migration in berea sandstone. SPE Journal. 2017.

2. Aksu I, Bazilevskaya E, Karpyn ZT. Swelling of clay minerals in unconsolidated porous media and its impact on permeability. Geo ResJ. 2015;7:1-13.
3. Azari M, Leimkuhler JM. Formation permeability damage induced by completion brines. Journal of Petroleum Technology. 1990;42(4):486-492.

4. Yustiningtyas L. Clay Minerals in Sandstone Reservoir Rocks Distribution, Diagenetic Evolution \& Potential Formation Damage. MTG. 2014;5(2).

5. Kaufman PB, Penny GS, Paktinat J. Critical evaluation of additives used in shale slickwater fracs. In: SPE Shale Gas Production Conference. Society of Petroleum Engineers. 2008.

6. Wilson MD, Pittman ED. Authigenic clays in sandstones: recognition and influence on reservoir properties and paleoenvironmental analysis. Journal of Sedimentary Research. 1977;47(1).

7. Houseknecht DW, Pittman ED. Origin, diagenesis, and petrophysics of clay minerals in sandstones. SEPM (Society for Sedimentary Geology). 1992.

8. Mungan N. Permeability reduction through changes in $\mathrm{pH}$ and salinity. Journal of Petroleum Technology. 1965;17(12):1-449.

9. Gray D, Rex R. Formation damage in sandstones caused by clay dispersion and migration. In: Clays and Clay Minerals: Proceedings of the Fourteenth National Conference. Elsevier. 1966;355-366.

10. Khilar KC, Fogler HS. Water sensitivity of sandstones. Society of Petroleum Engineers Journal. 1983;23(1):55-64.

11. Khilar KC, Fogler HS. The existence of a critical salt concentration for particle release. J Colloid Interface Sci. 1984;101(1):214-224.

12. Khilar K, Fogler H. Migrations of fines in porous media. Dordrecht, The Netherlands: Kluwer Academic Publishers. 1998.

13. Kia SF, Fogler HS, Reed MG. Effect of salt composition on clay release in Berea sandstones. In: SPE International Symposium on Oilfield Chemistry. Society of Petroleum Engineers. 1987.

14. Valdya RN, Fogler HS. Fines migration and formation damage: influence of $\mathrm{pH}$ and ion exchange. SPE production engineering. 1992;7(4):325-330.

15. Tchistiakov AA. Colloid chemistry of in-situ clay-induced formation damage. In: SPE International Symposium on Formation Damage Control. Society of Petroleum Engineers. 2000.

16. Mahmoud MA, Nasr-El-Din HA, DeWolf CA. Removing formation damage and stimulation of deep illitic-sandstone reservoirs using green fluids. In: SPE Annual Technical Conference and Exhibition. Society of Petroleum Engineers. 2011.

17. Mohan KK, Fogler HS, Vaidya RN, et al. Water sensitivity of sandstones containing swelling and non-swelling clays. In: Colloids in the Aquatic Environment. Elsevier. 1993;237-254.

18. Bhattacharya SS, Paitaridis J, Pedler A, et al. Fines mobilisation by lowsalinity water injection: 3-point-pressure tests. In: SPE International Conference and Exhibition on Formation Damage Control. Society of Petroleum Engineers. 2016.

19. Byrne M, Rojas E, Kandasamy R, et al. Fines migration in oil and gas reservoirs: quantification and qualification through detailed study. In: SPE International Symposium and Exhibition on Formation Damage Control. Society of Petroleum Engineers. 2014.

20. Civan F. Reservoir Formation Damage. $3^{\text {rd }}$ ed. Gulf Professional Publishing. 2015.

21. Bai T, Chen Z, Aminossadati SM, et al. Characterization of coal fines generation: A micro-scale investigation. Journal of Natural Gas Science and Engineering. 2015;27:862-875.

22. You Z, Bedrikovetsky P, Badalyan A, et al. Particle mobilization in porous media: temperature effects on competing electrostatic and drag forces. $J$ Nat Gas Sci Eng. 2015;42(8):2852-2860.

23. Wang W, Yuan B, Su Y, et al. Nanoparticles adsorption, straining and 
detachment behavior and its effects on permeability of berea cores: Analytical model and lab experiments. In: SPE Annual Technical Conference and Exhibition. Society of Petroleum Engineers. 2016.

24. Yuan B, Moghanloo RG, Zheng D. Analytical evaluation of nanoparticle application to mitigate fines migration in porous media. SPE Journal. 2016;21(6):2-317.

25. You Z, Yang Y, Badalyan A, et al. Mathematical modelling of fines migration in geothermal reservoirs. Geothermics. 2016;59:123-133.

26. Ohen HA, Civan F. Simulation of formation damage in petroleum reservoirs. SPE Advanced Technology Series. 1993;1(1):27-35.

27. Liu X, Civan F. Formation damage and filter cake buildup in laboratory core tests: modeling and model-assisted analysis. SPE Formation Evaluation. 1996;11(1):26-30.

28. Musharova D, Mohamed IM, Nasr-El-Din HA. Detrimental effect of temperature on fines migration in sandstone formations. In: SPE International Symposium and Exhibition on Formation Damage Control. Society of Petroleum Engineers. 2012.

29. Abedi LM, Vafaie SM, Baghban SM, et al. Gelation Time of Hexamethylenetetramine Polymer Gels Used in Water Shutoff Treatment. 2012

30. Guan LL, Du Y, Wang Z. Water injectivity-What we have learned in the past 30 years. In: Canadian International Petroleum Conference. Petroleum Society of Canada. 2005.

31. Civan F. Reservoir Formation Damage. Gulf Professional Publishing. 2000 .

32. Bennion DB, Bennion DW, Thomas FB, et al. Injection water quality-a key factor to successful waterflooding. Journal of Canadian Petroleum Technology. 1998;37(6).

33. Chang FF, Civan F. Predictability of formation damage by modeling chemical and mechanical processes. In: SPE Formation Damage Control Symposium. Society of Petroleum Engineers. 1992.

34. Abbasi S, Shahrabadi A, Golghanddashti H. Experimental Investigation of Clay Minerals' Effects on the Permeability. In: SPE European Formation Damage Conference. Society of Petroleum Engineers. 2011.

35. Civan F. Reservoir Formation Damage: Fundamentals. Modeling, Assessment, and Mitigation. 2007;2.
36. Das M, Medhi N. Clay Minerals and its importance on Hydrocarbon Production Potential in a part of Geleki oilfield of Upper Assam Basin. International Journal of Research in Engineering and Applied Sciences. 2015;5(11):25-33.

37. Awadh S, Al-Yaseri A, Hussein A. The Influence of Kaolinite and $\mathrm{pH}$ on Permeability in the Zubair Reservoir in the North Rumaila Oilfield, Southern Iraq. In: Third EAGE Workshop on Iraq. 2015.

38. Priisholm S, Nielsen BL, Haslund O. Fines migration, blocking, and clay swelling of potential geothermal sandstone reservoirs, Denmark. SPE Formation Evaluation. 1987;2(2):168-178.

39. Worden RH, Morad S. Clay mineral cements in sandstones. Blackwell Publishing. 2003.

40. Mungan N. Discussion of an overview of formation damage. Journal of petroleum technology. 1989;41(11).

41. Rosenbrand E, Kjøller C, Riis JF, et al. Different effects of temperature and salinity on permeability reduction by fines migration in Berea sandstone. Geothermics. 2015;53:225-235.

42. Brown G, Brindley GWi. Crystal structures of clay minerals and their X-ray identification. Mineralogical Society London; 1980;5.

43. Thorez J. Practical identification of clay minerals: a handbook for teachers and students in clay mineralogy. Ed. Lelotte. 1976.

44. Ransom MD, Bigham JM, Smeck NE, et al. Transitional vermiculitesmectite phases in Aqualfs of southwestern Ohio. Soil Sci Soc Am J. 1988;52(3):873-880.

45. Moore DM. Identification of clay minerals and associated minerals. $X$-Ray Diffraction and Analysis of Clay Minerals. 1997;227-260.

46. Fonseca RM, Barriga FJ, Conceição PI. Clay minerals in sediments of Portuguese reservoirs and their significance as weathering products from over-eroded soils: a comparative study of the Maranhão, Monte Novo and Divor Reservoirs (South Portugal). Int J Earth Sci. 2010;99(8):1899-1916.

47. Wilson MJ, Wilson L, Patey I. The influence of individual clay minerals on formation damage of reservoir sandstones: a critical review with some new insights. Clay Miner. 2014;49(2):147-164. 